\title{
Effects of a biologic agent in a patient with rheumatoid arthritis after treatment for methotrexate-associated B-cell lymphoma: a case report
}

Takeshi Kuroda ${ }^{1,2^{*}}$, Hiroe Sato ${ }^{2}$, Takeshi Nakatsue ${ }^{2}$, Yoko Wada², Shuichi Murakami², Masaaki Nakano ${ }^{3}$ and Ichiei Narita ${ }^{2}$

\begin{abstract}
Background: Several studies have suggested an increased risk of malignant tumor in patients with rheumatoid arthritis. It has been also reported that rheumatoid arthritis patients have a high incidence of lymphoma compared with the general population, and that patients receiving methotrexate, which is the anchor drug for rheumatoid arthritis treatment, can develop lymphoproliferative disease. Nevertheless, management of rheumatoid arthritis after treatment for methotrexate-associated lymphoma has not been fully investigated. We here report a patient with rheumatoid arthritis who developed malignant lymphoma associated with methotrexate therapy. Moreover, we describe the use of a biologic agent for a rheumatoid arthritis patient after treatment for lymphoma associated with methotrexate.
\end{abstract}

Case presentation: A 60-year-old Japanese man with a 20-year history of rheumatoid arthritis was admitted to our hospital with a left inguinal tumor. Open biopsy was performed and a biopsy specimen revealed diffuse large B-cell lymphoma. As our patient had received methotrexate for 4 years, we diagnosed the lymphoproliferative disease as being methotrexate-related. This lymphoma was not associated with Epstein- Barr virus by Epstein-Barr virus-encoded ribonucleic acid in-situ hybridization, but this patient was an Epstein-Barr virus carrier, regarding serological testing. The lymphoma went into complete remission after 6 courses of rituximab plus cyclophosphamide, hydroxydaunorubicin, vincristine, and prednisone/prednisolone therapy. Two years later, however, rheumatoid arthritis activity gradually increased and was not controlled with salazosulfapyridine. Etanercept was administered in view of its possible effect on B-cells, and this reduced the level of disease activity without recurrence of lymphoma.

Conclusion: The management of rheumatoid arthritis after treatment for methotrexate-associated lymphoma has not been fully investigated yet. Etanercept appeared to be safe because of its B-cell effect, but further observation is necessary to make a firm conclusion. Further accumulation of cases is needed to clarify which biologics are safe and effective for treatment of methotrexate-associated B-cell lymphoma.

Keywords: Rheumatoid arthritis, Lymphoma, Biologics

\footnotetext{
* Correspondence: kurodat@med.niigata-u.ac.jp

${ }^{1}$ Niigata University Health Administration Center, 2-8050 Ikarashi, Nishi-ku,

Niigata City 950-2181, Japan

${ }^{2}$ Division of Clinical Nephrology and Rheumatology, Niigata University

Graduate School of Medical and Dental Sciences, 1-757 Asahimachi-Dori,

Chuo-ku, Niigata City 951-8510, Japan

Full list of author information is available at the end of the article
}

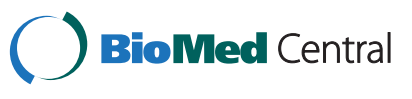

(c) 2014 Kuroda et al.; licensee BioMed Central Ltd. This is an Open Access article distributed under the terms of the Creative Commons Attribution License (http://creativecommons.org/licenses/by/2.0), which permits unrestricted use, distribution, and reproduction in any medium, provided the original work is properly credited. The Creative Commons Public Domain Dedication waiver (http://creativecommons.org/publicdomain/zero/1.0/) applies to the data made available in this article, unless otherwise stated. 


\section{Background}

Rheumatoid arthritis (RA) is a chronic inflammatory disease characterized by painful swollen joints, impaired mobility of the affected joints and permanent damage to the cartilage and bone. Methotrexate (MTX) is an anchor drug in the treatment of RA, and has been shown to delay the progression of radiographic changes in the joints, halt worsening of the quality of life, and prolong the life span of patients with RA [1,2].

However, a proportion of patients receiving MTX therapy may develop potentially life-threatening adverse events such as interstitial pneumonia [3-9], severe bone marrow suppression $[10,11]$ and lymphoproliferative disease (LPD), including malignant lymphoma [12-15]. Until now, there has been some debate over whether MTX therapy for RA patients is associated with an increasing risk of developing lymphoma [16-18].

Here we report a patient with RA who sequentially developed diffuse large B-cell lymphoma (DLBCL) during a 4-year course of MTX therapy. We also discuss the clinical effects and safety of biologics after treatment of lymphoma.

\section{Case presentation}

A 60-year-old Japanese man with a 20-year history of RA was admitted to our hospital with a left inguinal tumor in May 2011. His family history included no consanguinity or collagen diseases. He had first developed polyarthralgia in March 2003, and visited our satellite hospital. A diagnosis of RA was made, based on the presence of symmetrical polyarthritis involving the hands, elbows and knees, and positivity for serum rheumatoid factor (RF). Initially he was treated with bucillamine $(100 \mathrm{mg} /$ day $)$ and prednisolone ( $2.5 \mathrm{mg} /$ day), but this was soon switched to salazosulfapyridine $(500 \mathrm{mg} /$ day). His RA disease activity temporarily subsided, but later flared up again in May 2007. In June 2007, MTX was substituted for salazosulfapyridine at the dose of $6 \mathrm{mg} /$ week. Treatment with tacrolimus was added in December 2008 at a dose of $1 \mathrm{mg}$ daily, and was soon increased to $2 \mathrm{mg}$ daily. Tacrolimus was switched to mizoribine (100 mg/day) in March 2009, because the arthritis was not controlled. Therefore, the dose of MTX ( $8 \mathrm{mg} /$ week) was increased along with mizoribine ( $8 \mathrm{mg} /$ week) in November 2011. The patient showed gradual resolution of his articular symptoms in response to MTX.

In April 2011, he noticed a mass about $3 \mathrm{~cm}$ in diameter in his left inguinal region, and this increased rapidly in size over the next month. Abdominal contrast computed tomography (CT) revealed a mass, approximately $7.0 \mathrm{~cm}$ in diameter, in the left inguinal region and involving the external iliac vein (Figure 1). Additionally, there was a thrombus in the distal part of the left external iliac vein: therefore, he was referred to our hospital on May 31. While scheduled to undergo a biopsy of the mass, he was admitted on May 31. At that time, there was no evidence of active synovitis.

On physical examination, his blood pressure was $120 / 62 \mathrm{mmHg}$ with a regular heartbeat of $80 \mathrm{bpm}$ and a temperature of $36.0^{\circ} \mathrm{C}$. Pulse oximetry showed an oxygen saturation of $98 \%$. Cardiac, lung and abdominal examination revealed no abnormalities. Marked left foot edema was observed. Neurological examination revealed no abnormalities. There was symmetric polyarthritis in the proximal interphalangeal and metacarpophalangeal joints of the hand, wrist, and ankle. Laboratory studies revealed a leukocyte count of 5740 per $\mathrm{mm}^{3}$, a red blood cell count of $387 \times 10^{4}$ per $\mathrm{mm}^{3}$, a hematocrit of $39.2 \%$, hemoglobin $12.7 \mathrm{~g} / \mathrm{dL}$, platelet count $22.9 \times 10^{4}$ per $\mathrm{mm}^{3}$, and a Creactive protein level of $11.35 \mathrm{mg} / \mathrm{dL}$. Electrolytes were normal with a total protein level of $7.1 \mathrm{~g} / \mathrm{dL}$ and hypoalbuminemia $(2.9 \mathrm{~g} / \mathrm{dL})$. The blood urea nitrogen concentration was $13.0 \mathrm{mg} / \mathrm{dL}$, and the serum creatinine level was $0.68 \mathrm{mg} / \mathrm{dL}$. Urinalysis showed a urinary protein excretion of $0.1 \mathrm{~g} /$ day, and no hematuria. His level of RF was $127.0 \mathrm{IU} / \mathrm{mL}$ and anti-cyclic citrullinated peptide antibody was $801.8 \mathrm{U} / \mathrm{mL}$; antinuclear antibodies were negative. Blood tests revealed the following values: alanine transaminase $90 \mathrm{IU} / \mathrm{L}$, aspartate aminotransferase $71 \mathrm{IU} / \mathrm{L}$, alkaline phosphatase $608 \mathrm{IU} / \mathrm{L}$, lactate dehydrogenase $394 \mathrm{IU} / \mathrm{L}$, glutamyl transaminase $187 \mathrm{IU} / \mathrm{L}$, total bilirubin $2.8 \mathrm{mg} / \mathrm{dL}$, total cholesterol $196 \mathrm{mg} / \mathrm{dL}$, and triglyceride $113 \mathrm{mg} / \mathrm{dL}$. The serum immunoglobulin (Ig) levels were as follows: IgG: $1171 \mathrm{mg} / \mathrm{dL}$; IgA: $401 \mathrm{mg} /$ $\mathrm{dL}$; IgM: $65 \mathrm{mg} / \mathrm{dL}$. The serum carcinoembryonic antigen level was $1.5 \mathrm{ng} / \mathrm{mL}$ (normal range, $1.0-6.7 \mathrm{ng} / \mathrm{mL}$ ), squamous cell carcinoma antigen level $0.5 \mathrm{ng} / \mathrm{mL}$ (normal range, $<1.5 \mathrm{ng} / \mathrm{mL}$ ), carbohydrate antigen- $12524.0 \mathrm{ng} / \mathrm{mL}$ (normal range, $<35 \mathrm{ng} / \mathrm{mL}$ ), $\alpha$-fetoprotein $3.0 \mathrm{ng} / \mathrm{mL}$ (normal range $<10 \mathrm{ng} / \mathrm{mL}$ ), prostate specific antigen $0.54 \mathrm{ng} /$ $\mathrm{mL}$ (normal range $<3.0 \mathrm{ng} / \mathrm{mL}$ ), and carbohydrate antigen 19-9 $5 \mathrm{U} / \mathrm{mL}$ (normal range, $<37 \mathrm{U} / \mathrm{mL}$ ). The soluble interleukin-2 receptor level was elevated to $1168 \mathrm{U} / \mathrm{mL}$ (normal range, 220-530 U/mL). Notably, serum IgG reaction with Epstein-Barr virus (EBV)-viral capsid antigen (VCA) was positive (1/160), serum IgA reaction with EBV VCA was negative $(<1 / 10)$, serum IgM reaction with EBV VCA was negative $(<1 / 10)$, serum IgG reaction with EBVearly antigen (EBV-EA) was negative $(<1 / 10)$, serum IgA reaction with EBV-EA was negative $(<1 / 10)$, and that with the nuclear antigen was positive $(1 / 20)$ (normal range, $<1 /$ 10). Additionally, chest $X$-ray showed no abnormalities.

A CT scan of the abdomen and chest showed no ascites and no lymphadenopathy except for the left inguinal tumor with involvement of the left external iliac artery. Histological analysis of a biopsied lymph node revealed DLBCL with cluster of differentiation (CD) $20^{+}, \mathrm{CD}^{-}$ and negativity for EBV-encoded ribonucleic acid (EBER) 


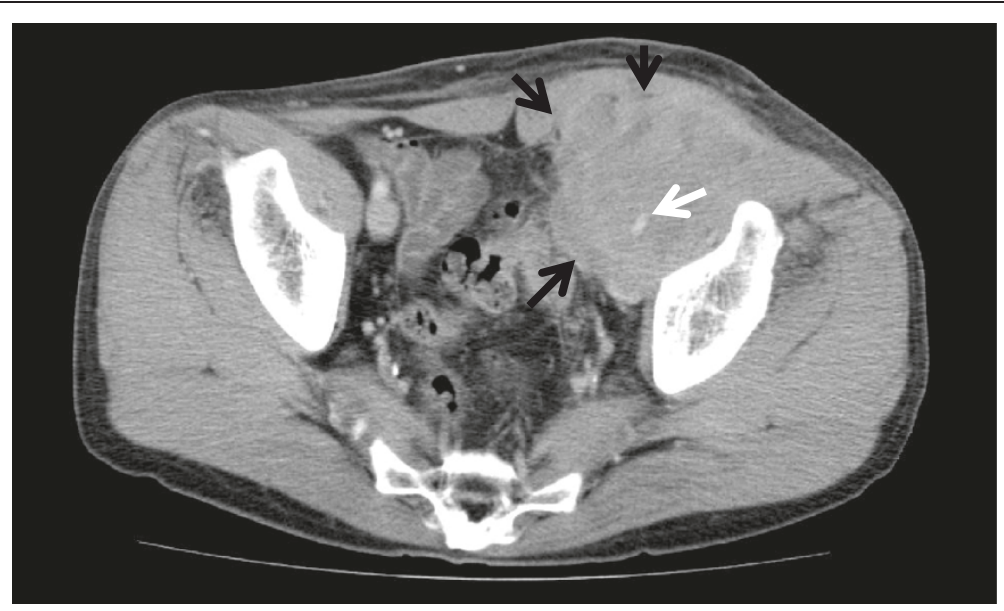

Figure 1 Abdominal contrast computed tomography revealed that a mass, approximately $7.0 \mathrm{~cm}$ in diameter (black arrows), was detected in the left inguinal region and the tumor involved the external iliac vein (white arrow).

in-situ hybridization (ISH). Flow cytometry analysis showed a pathological cell phenotype of $\mathrm{CD} 19^{+}, \mathrm{CD} 20^{+}$, $\mathrm{CD}_{2}{ }^{+}, \mathrm{CD}^{-}, \mathrm{CD} 10^{-}$and B-cell type. Cytogenetic analysis detected 45, X, -Y [3] /46, XY [17], indicating deletion of chromosome $\mathrm{Y}$. After diagnosis of lymphoma, the patient received six courses of chemotherapy (RCHOP: rituximab, cyclophosphamide, adriamycin, vincristine, prednisone). After the first chemotherapy cycle, his foot edema began to improve and the left inguinal tumor suddenly became non-palpable. CT scans of the abdomen and chest taken in July 2011 revealed complete resolution of the lymph node enlargement, and complete remission of the DLBCL. He was discharged from hospital in July 2011, and followed up as an outpatient. His RA activity then gradually increased with symmetrical polyarthritis involving the hands, elbows and knees, and therefore salazosulfapyridine (1000 mg/day) and prednisolone (10 mg/day) were readministered. The RA disease activity became temporarily quiescent, but later flared up again in March 2013. Therefore, in May 2013, etanercept was added at $25 \mathrm{mg}$ twice a week without MTX to control the arthritis, and thereafter the RA activity gradually improved. The disease activity score 28 erythrocyte sedimentation rate (DAS28-ESR) was 2.8 in August 2013 without any side effects or recurrence of the lymphoma.

\section{Conclusions}

Several studies have suggested an increased risk of malignant tumor in patients with RA [19-21], but the majority of reports have noted that the risk is not increased to a significant degree [22-26]. Whether or not RA patients treated with MTX have an increased risk of developing lymphoma remains a matter of controversy. It has been reported that RA patients have a high incidence of lymphoma compared with the general population, and that patients receiving MTX, which is the anchor drug for RA treatment, can develop LPD [12]. The risk of malignant lymphoma in patients with RA has been estimated to be 1.9-6.7 times that in the general population [20,21,24,26,27]. Recently, several reports have suggested that EBV infection might be related to LPD associated with MTX [13,28]. EBV is a B-lymphocytotropic virus causing a variety of B-cell disorders, including infectious mononucleosis and LPD in patients who are immunosuppressed. Moreover, other reports have indicated that many spontaneous malignant lymphomas have become attenuated by withdrawal of MTX treatment alone [29,30]. These reports clearly indicate that MTX induces LPD. However, the relationship between the duration of MTX treatment and the onset of LPD [18,31] still remains unclear. Several epidemiological studies have failed to find any overall association between MTX exposure and the development of lymphoma in RA patients [18,32-34]. By contrast, it has been reported that the risk of lymphoma is higher in RA patients with high disease activity [35]. Thus, it is considered that MTX treatment reduces the disease activity of RA, leading to suppression for LPD, whereas MTX treatment induces LPD and EBV-related LPD in immunosuppressed patients. With regard to the histopathological type of lymphoma, a previous report has revealed that $78 \%$ of RA patients have B-cell lymphoma, $5 \%$ have T-natural killer-cell lymphoma, and 6\% have Hodgkin's disease; $48 \%$ of B-cell malignant lymphomas in RA patients were been identified as DLBCL, which is the most common form [35]. In our patient the lymphoma was diagnosed as DLBCL and the disease activity of RA could not be sufficiently controlled. As our patient had received MTX for 4 years, we diagnosed the LPD as being MTXrelated. This lymphoma was not associated with EBV by EBER-ISH, but this patient was an EBV carrier, regarding serological test. 
As for anti-tumor necrosis factor (TNF) therapy, the association between anti-TNF therapy and malignant lymphoma was also unclear. Several reports have indicated that patients receiving anti-TNF antibody therapy had no significantly increased risk of developing malignant lymphoma $[21,36]$. However, another report has indicated that patients receiving anti-TNF antibody therapy had a significantly higher incidence of lymphoma than patients without anti-TNF antibody therapy [37]. According to a metaanalysis of nine large-scale clinical trials involving RA patients, the risk of developing a malignant tumor was 3.3 times higher than in controls [38]. There was considerable variation among individual cases, but the situation was complicated by several factors, and epidemiologic trends were unclear. After treatment for malignant lymphoma, our patient achieved complete remission with rituximab, but the disease activity of RA gradually became higher again. In this case, we determined that MTX was contraindicated and administered salazosulfapyridine first, but it was not effective. Therefore we decided to use biologics.

The rationale for treatment of lymphoma with a TNF inhibitor is still unclear. Although a direct action of TNF or anti-TNF on B-cells has been hypothesized, no increase in survival or apoptosis has been found [18,39]. Anti-TNF agents can be structurally classified into two types; one type is generated as an antibody against human TNF- $\alpha$ and the other type is engineered from human TNF receptors. The former type includes infliximab, adalimumab, and golimumab, and the latter type is etanercept. Biologic treatments are known to affect B-cells. AntiTNF antibodies such as infliximab and adalimumab show complement-dependent cytotoxicity (CDC), antibodydependent cell-mediated cytotoxicity (ADCC), and outside-to-inside signaling (apoptosis/cell cycle arrest) via transmembrane TNF- $\alpha$, whereas etanercept has only ADCC activity and lacks CDC activity and outside-toinside signaling via transmembrane TNF- $\alpha$ in vitro [40]. Transmembrane TNF- $\alpha$ is also known to exert unique biologic functions such as cytotoxic activity and polyclonal B-cell activation, in a cell-to-cell contact manner. Tocilizumab, an anti-interleukin-6 receptor inhibitor, reduces the frequency of peripheral preswitching and post-switch memory B-cells [41]. For this reason, we did not choose tocilizumab for the present patient. Additionally, it has been reported that both abatacept [42], a fusion protein composed of immunoglobulin fused to the extracellular domain of cytotoxic T-lymphocyte antigen 4, and certolizumab pegol [43], a humanised anti-TNF pegylated Fab' fragment do not mediate CDC and ADCC. Considering the features of these biologics and the fact that our patient had DLBCL with B-cell surface markers, we thought that etanercept would be safer than other biologics. Our patient achieved low disease activity without recurrence of malignant lymphoma after 5 months of treatment. If the response with etanercept is lost, abatacept or certolizumab pegol might be chosen.

Here we have described the use of a biologic agent for an RA patient after treatment for B-cell lymphoma associated with MTX. We chose etanercept for our patient considering its influence on B-cells, and he achieved low disease activity. Etanercept appeared to be safe because of its B-cell effect, but further observation is necessary to make a firm conclusion. Further accumulation of cases is needed to clarify which biologics are safe and effective in this situation.

\section{Consent}

Written informed consent was obtained from the patient for publication of this case report and any accompanying images. A copy of the written consent is available for review from the Editor-in-Chief of this journal.

\section{Competing interests}

The authors declare that they have no competing interests.

\section{Authors' contributions}

TK, HS, TN, YW and SM made substantial contributions to the conception and design, and the acquisition, analysis, and interpretation of data. They were also involved in drafting and revising the manuscript. MN and IN contributed to the conception and design, and performed critical revision of the manuscript. All authors read and approved the final manuscript.

\section{Acknowledgement}

This work was supported by a grant for Yukjin Kikin, Niigata University.

\section{Author details}

${ }^{1}$ Niigata University Health Administration Center, 2-8050 Ikarashi, Nishi-ku, Niigata City 950-2181, Japan. ${ }^{2}$ Division of Clinical Nephrology and Rheumatology, Niigata University Graduate School of Medical and Dental Sciences, 1-757 Asahimachi-Dori, Chuo-ku, Niigata City 951-8510, Japan. ${ }^{3}$ Department of Medical Technology, School of Health Sciences, Faculty of Medicine, Niigata University, 2-746 Asahimachi-Dori, Chuo-ku, Niigata City 951-8518, Japan.

Received: 10 September 2013 Accepted: 31 March 2014 Published: 11 April 2014

\section{References}

1. Pincus T, Ferraccioli G, Sokka T, Larsen A, Rau R, Kushner I, Wolfe F: Evidence from clinical trials and long-term observational studies that disease-modifying anti-rheumatic drugs slow radiographic progression in rheumatoid arthritis: updating a 1983 review. Rheumatology (Oxford) 2002, 41:1346-1356.

2. Krause D, Scleusser B, Herborn G, Rau R: Response to methotrexate treatment is associated with reduced mortality in patients with severe rheumatoid arthritis. Arthritis Rheum 2000, 43:14-21.

3. Searles G, McKendry RJR: Methotrexate pneumonitis in rheumatoid arthritis: potential risk factors. Four cases reports and a review of the literature. J Rheumatol 1987, 14:1164-1171.

4. Carson CW, Cannon GW, Egger MJ, Ward JR, Clegg DO: Pulmonary disease during the treatment of rheumatoid arthritis with low dose pulse methotrexate. Semin Arthritis Rheum 1987, 16:186-195.

5. Carroll GJ, Thomas R, Phatouros CC, Atchison MH, Lesile AL, Cook NJ, D'Souza I: Incidence, prevalence and possible risk factors for pneumonitis in patients with rheumatoid arthritis receiving methotrexate. J Rheumatol 1994, 21:51-54.

6. Ohosone $Y$, Okano $Y$, Kameda H, Fujii T, Hama N, Hirakata M, Mimori T, Akizuki M, Ikeda Y: Clinical characteristics of patients with rheumatoid arthritis and methotrexate induced pneumonitis. J Rheumatol 1997, 24:2299-2303 
7. Kremer JM, Alarcon GS, Weinblatt ME, Kaymakcian MV, Macaluso M, Cannon GW, Palmer WR, Sundy JS, St. Clair EW, Alexander RW, Smith GJ, Axiotis CA: Clinical, laboratory, radiographic, and histopathologic features of methotrexate-associated lung injury in patients with rheumatoid arthritis: a multicenter study with literature review. Arthritis Rheum 1997, 40:1829-1837.

8. Cannon GW: Methotrexate pulmonary toxicity. Rheum Dis Clin North Am 1997, 23:917-937.

9. Imokawa S, Colby TV, Leslie KO, Helmers RA: Methotraxate pneumonitis: review of the literature and histopathological findings in nine patients. Eur Respir J 2000, 15:373-381.

10. Gutierrez-Urena S, Molina JF, García CO, Cuéllar ML, Espinoza LR: Pancytopenia secondary to methotrexate therapy in rheumatoid arthritis. Arthritis Rheum 1996, 39:272-276.

11. Ohosone $Y$, Okano $Y$, Kameda H, Hama N, Mimori T, Akizuki M, Ikeda Y: Clinical characteristics related to methotrexate-induced pancytopenia. Clin Rheumatol 1997, 16:321-323.

12. Georgescu L, Quinn GC, Schwartzman S, Paget SA: Lymphoma in patients with rheumatoid arthritis: association with the disease state or methotrexate treatment. Semin Arthritis Rheum 1997, 26:794-804.

13. Feng W-H, Cohen Jl, Fischer S, Li L, Sneller M, Goldbach-Mansky R, Raab-Traub N, Delecluse HJ, Kenney SC: Reactivation of latent Epstein-Barr virus by methotrexate: a potential contributor to methotrexate-associated lymphomas. J Natl Cancer Inst 2004, 96:1691-1702.

14. Baird RD, van Zyl-Smit RN, Dilke T, Scott SE, Rassam SMB: Spontaneous remission of low-grade B-cell non-Hodgkin's lymphoma following withdrawal of methotrexate in a patient with rheumatoid arthritis: case report and review of the literature. Br J Haematol 2002, 118:567-568.

15. Ebeo CT, Girish MR, Byrd RP, Roy TM, Mehta JB: Methotrexate-induced pulmonary lymphoma. Chest 2003, 123:2150-2153.

16. Kamel OW, Holly EA, van de Rijn M, Lele C, Sah A: A population based, case control study of non-Hodgkin's lymphoma in patients with rheumatoid arthritis. J Rheumatol 1999, 26:1676-1680.

17. Usman AR, Yunus MB: Non-Hodgkin's lymphoma in patients with rheumatoid arthritis treated with low dose methotrexate. J Rheumatol 1996, 23:1095-1097.

18. Mariette X, Cazals-Hatem D, Warszawki J, Liote F, Balandraud N, Sibilia J, Investigators of the Club Rhumatismes et Inflammation: Lymphomas in rheumatoid arthritis patients treated with methotrexate: a 3-year prospective study in France. Blood 2002, 99:3909-3915.

19. Kauppi M, Pukkala E, Isomäki H: Excess risk of lung cancer in patients with rheumatoid arthritis. J Rheumatol 1996, 23:1484-1485.

20. Mellemkjaer L, Linet MS, Gridley G, Frisch M, Møller H, Olsen JH: Rheumatoid arthritis and cancer risk. Eur J Cancer 1996, 32:1753-1757.

21. Askling J, Fored CM, Brandt L, Baecklund E, Bertilsson L, Feltelius N, Cöster L, Geborek P, Jacobsson LT, Lindblad S, Lysholm J, Rantapää-Dahlqvist S, Saxne T, Klareskog L: Risks of solid cancers in patients with rheumatoid arthritis and after treatment with tumour necrosis factor antagonists. Ann Rheum Dis 2005, 64:1421-1426.

22. Katusic S, Beard CM, Kurland LT, Weis JW, Bergstralh E: Occurrence of malignant neoplasms in the Rochester, Minnesota, rheumatoid arthritis cohort. Am J Med 1985, 78:50-55.

23. Cibere J, Sibley J, Haga M: Rheumatoid arthritis and the risk of malignancy. Arthritis Rheum 1997, 40:1580-1586.

24. Thomas E, Brewster DH, Black RJ, Macfarlane GJ: Risk of malignancy among patients with rheumatic conditions. Int J Cancer 2000, 88:497-502.

25. Ekstorm K, Hjalgrim H, Brandt L, Baecklund E, Klareskog L, Ekbom A, Askling J: Risk of malignant lymphomas in patients with rheumatoid arthritis and in their first degree relatives. Arthritis Rheum 2003, 48:963-970.

26. Chiba N: The incidence of cancer among Japanese patients with rheumatoid arthritis in 2003 obtained by using Ninja. Mod Rheumatol 2006, 16(Suppl):202.

27. Wolfe F, Michaud K: Lymphoma in rheumatoid arthritis: the effect of methotrexate and anti-tumor necrosis factor therapy in 18,572 patients. Arthritis Rheum 2004, 50:1740-1751.

28. Kameda H, Okuyama A, Tamaru J, Itoyama S, lizuka A, Takeuchi T: Lymphomatoid granulomatosis and diffuse alveolar damage associated with methotrexate therapy in a patient with rheumatoid arthritis. Clin Rheumatol 2007, 26:1585-1589.

29. Kamel OW, van de Rijn M, Weiss LM, Del Zoppo GJ, Hench PK, Robbins BA Montgomery PG, Warnke RA, Dorfman RF: Brief report: reversible lymphomas associated with Epstein-Barr virus occurring during methotrexate therapy for rheumatoid arthritis and dermatomyositis. N Engl J Med 1993, 328:1317-1321.

30. Shimada K, Matsui T, Kawakami M, Nakayama H, Ozawa Y, Mitomi H, Tohma S: Methotrexate-related lymphomatoid granulomatosis: a case report of spontaneous regression of large tumours in multiple organs after cessation of methotrexate therapy in rheumatoid arthritis. Scand J Rheumatol 2007, 36:64-67.

31. Kamel OW, Cooper DL, Howe G, Lacy J, Tallini G, Crouch J, Schultz M, Murren J: Spontaneous regression of lymphoproliferative disorders in patients treated with methotrexate for rheumatoid arthritis and other rheumatic diseases. J Clin Oncol 1996, 14:1943-1949.

32. Kremer JM: Safety, efficacy and mortality in a long-term cohort of patients with rheumatoid arthritis taking methotrexate: follow-up after a mean of 13.3 years. Arthritis Rheum 1997, 40:984-985.

33. Weinblatt ME, Maier AL, Fraser PA, Coblyn JS: Long-term prospective study of methotrexate in rheumatoid arthritis: conclusion after 132 months of therapy. J Rheumatol 1998, 25:238-242.

34. Baecklund E, Iliadou A, Askling J, Ekbom A, Backlin C, Granath F, Catrina Al, Rosenquist R, Feltelius N, Sundström C, Klareskog L: Association of chronic inflammation not its treatment, with increased lymphoma risk in rheumatoid arthritis. Arthritis Rheum 2006, 54:692-701.

35. Baecklund E, Ekbom A, Sparen P, Feltelius N, Klareskog L: Disease activity and risk of lymphoma in patients with rheumatoid arthritis: nested case-control study. Br Med J 1998, 317:180-181

36. Wolfe F, Michaud K: The effect of methotrexate and anti-tumor necrosis factor therapy on the risk of lymphoma in rheumatoid arthritis in 19,562 patients during 89,710 person-years of observation. Arthritis Rheum 2007, 56:1433-1439.

37. Geborek P, Bladström A, Turesson C, Gulfe A, Petersson IF, Saxne T, Olsson $H$, Jacobsson LT: Tumour necrosis factor blockers do not increase overall tumour risk in patients with rheumatoid arthritis, but may be associated with an increased risk of lymphomas. Ann Rheum Dis 2005, 64:699-703.

38. Bongartz T, Sutton AJ, Sweeting MJ, Buchan I, Matteson EL, Montori V: Anti-TNF antibody therapy in rheumatoid arthritis and the risk of serious infections and malignancies. JAMA 2006, 295:2275-2285.

39. Baran-Marszak F, Laguillier C, Youlyouz I, Feuillard J, Mariette X, Fagard R, Raphaël M: Effect of tumor necrosis factor alpha and infliximab on apoptosis of B lymphocytes infected or not with Epstein-Barr virus. Cytokine 2006, 33:337-345.

40. Mitoma H, Horiuchi T, Tsukamoto H, Tamimoto $Y$, Kimoto $Y$, Uchino A, To K, Harashima S, Hatta N, Harada M: Mechanisms for cytotoxic effects of anti-tumor necrosis factor agents on transmembrane tumor necrosis factor alpha-expressing cells: comparison among infliximab, etanercept, and adalimumab. Arthritis Rheum 2008, 58:1248-1257.

41. Roll P, Muhammad K, Schumann M, Kleinert S, Einsele H, Dörner T, Tony HP. In vivo effects of the anti-interleukin- 6 receptor inhibitor tocilizumab on the B cell compartment. Arthritis Rheum 2011, 63:1255-1264.

42. Davis PM, Abraham R, Xu L, Nadler SG, Suchard SJ: Abatacept binds to the Fc receptor CD64 but does not mediate complement-dependent cytotoxicity or antibody-dependent cellular cytotoxicity. J Rheumatol 2007, 34:2204-2210.

43. Nesbitt A, Fossati G, Bergin M, Stephens P, Stephens S, Foulkes R, Brown D Robinson M, Bourne T: Mechanism of action of certolizumab pegol (CDP870): in vitro comparison with other anti-tumor necrosis factor alpha agents. Inflamm Bowel Dis 2007, 13:1323-1332

\section{doi:10.1186/1756-0500-7-229}

Cite this article as: Kuroda et al:: Effects of a biologic agent in a patient with rheumatoid arthritis after treatment for methotrexate-associated B-cell lymphoma: a case report. BMC Research Notes 2014 7:229. 